\title{
Longevity of Cratonic Mantle Beneath an Active Rift: Re-Os evidence from Xenoliths from the Tanzanian East African Rift
}

\author{
Chesley, J.T. ${ }^{1}$, Rudnick, R.L. ${ }^{2}$ and Lee, C.-T. ${ }^{2}$
}

1. Dept. of Geological Sciences, University of Arizona, Gould-Simpson Building, Tucson, AZ 85721, U.S.A.

2. Dept. of Earth and Planetary Sciences, Harvard University, 20 Oxford St., Cambridge, MA 02138, U.S.A.

In recent years the Re-Os isotopic system has been applied to dating melt extraction events in peridotites with great success owing to the fact that Re is a moderately incompatible element (behaving like $\mathrm{Yb}$ or $\mathrm{Al}$ ) during mantle melting (McDonough, 1994), whereas Os is strongly compatible (bulk D of 20 to $>200$, Hart and Ravizza, 1996). Melting thus dramatically lowers the $\mathrm{Re} / \mathrm{Os}$ ratio of residual peridotites and slows the Os isotopic evolution from the time of melting. Estimates of the time of the melting can be determined in several ways: 1) from Re-Os isochrons, 2) from Re-Os model ages ( $T_{M A}$ ) -- the intersection of the rock's Os isotopic evolution with the Os evolution of primitive mantle, based on measured ${ }^{187} \mathrm{Re} / 188 \mathrm{Os}$ and $187 \mathrm{Os} / 188 \mathrm{Os}$ of the sample (analogous to $\mathrm{Nd}$ model ages), or 3) from Re-depletion model ages ( $\mathrm{T}_{\mathrm{RD}}$ ); this method assumes there is no intrinsic Re in the peridotite and the measured ${ }^{187} \mathrm{Os} / 188 \mathrm{Os}$ is compared to the mantle evolution to determine the age (this age represents the minimum age of melt depletion). In practice, true $\mathrm{Re}-\mathrm{Os}$ isochrons are rare, owing to the relative mobility of $\mathrm{Re}$ during surface weathering and, in the case of xenoliths, addition of Re during host-rock reactions. However, other less mobile elements such as $\mathrm{Al}$ or the HREE can be used as proxies for Re contents, and thus linear correlations between these elements and ${ }^{187} \mathrm{Os} /{ }^{188} \mathrm{Os}$ have been used to estimate the initial ${ }^{187} \mathrm{Os} /{ }^{188} \mathrm{Os}$ ratio, hence time of melt extraction, for massif peridotites (Reisberg and Lorand, 1995). As melt extraction is generally linked to the timing of lithospheric growth, these ages are used to date lithosphere formation, which for cratonic xenolith suites generally corresponds very well to the age of the overlying crust (e.g., Pearson et al., 1995).

We have applied the Re-Os technique to peridotite xenoliths from the Labait tuff cone, a rift-related Pleistocene olivine melilitite that erupted near the Archean-Proterozoic boundary of the Tanzanian craton (Dawson et al., 1997; Lee and Rudnick, 1998; Rudnick et al., 1998). The Tanzanian craton contains greenstone successions and late Archean granitoids, the latter of which fall into two age groups (2.74 and $2.54 \mathrm{Ga}$ ), based on $\mathrm{Rb}$-Sr whole rock analyses of 18 plutons (Bell and Dodson, 1980). The age of the greenstones is largely unknown. The Archean craton is surrounded by Proterozoic mobile belts; directly to the east of Labait lie rocks of the $2.1 \mathrm{Ga}$ Usagaran belt, which were metamorphosed during pan-African (700 Ma) collision. Rifting developed in the Cenozoic, with the eastern arm of the rift propagating southwards from Kenya in the Neogene (Dawson, 1992). Geophysically, the Tanzanian craton is characterized by high elevation, a negative Bouger gravity anomaly (Ebinger et al., 1997) and low heat flow (Nyblade et al., 1990). Results from a recent broad-band seismic experiment show that the Tanzanian mantle root is largely intact beneath the craton, that the uplift and negative gravity anomaly are due to hot, low density material beneath the cratonic root and that erosion and/or heating of this ancient root is confined to the vicinity of the rift (Ritsema et al., 1998). Our xenolith studies at Labait provide first-hand observations on how rifting is affecting this cratonic root.

\section{Samples}

Peridotites found at Labait span a wide range of compositions and mineralogies (see Lee and Rudnick, 1998): spinel facies harzburgites and lherzolites, chromite-bearing harzburgites, garnet harzburgites and lherzolites as well as Fe-rich dunites, pyroxenites and glimmerites. We have concentrated our initial efforts on the refractory peridotites in order to investigate the timing of lithosphere formation.

P-T estimates for the garnet peridotites fall in a scattered field near a geotherm of $\sim 50 \mathrm{~mW} / \mathrm{m}^{2}$ (Dawson et al., 1997; Lee and Rudnick, 1998). There is an overall correlation between bulk composition and depth, with more fertile peridotites occurring at deeper levels (Lee and Rudnick, 1998). Trace element compositions show LILE enrichments, similar to cratonic mantle xenoliths elsewhere. Metasomatic overprinting by carbonatites and Fe-rich silicate melts is inferred from 
petrography and trace element compositions. At least one stage of this metasomatism is riftrelated, based on U-Pb dating of Pleistocene metasomatic zircons (Rudnick et al., 1998). Re-Os measurements were performed on 1 spinel facies harzburgite, 1 gt harzburgite, 5 gt lherzolites, 5 gtfree, chromite-bearing harzburgites, one Cr-diopsidite and one glimmerite. In addition, the Os isotopic compositions of chromite separates and their abraded rims were also determined in order to estimate the initial ${ }^{187} \mathrm{Os} /{ }^{188} \mathrm{Os}$ of the peridotites.

\section{Results}

Bulk rock Os concentrations range from a low of $0.42 \mathrm{ppb}$ in the glimmerite to a high of $4.8 \mathrm{ppb}$ in a gt-free harzburgite, showing a general correlation with fertility: harzburgites have the highest concentrations, lherzolites have intermediate concentrations, and the metasomatic rocks (glimmerite and pyroxenite) have the lowest Os concentrations. Os contents do not correlate with the amount of sulfides optically visible in the samples (consistent with the observations of Reisberg and Lorand, 1995). Re concentrations range from a low of $0.036 \mathrm{ppb}$ in the glimmerite to a high of $0.404 \mathrm{ppb}$ in a garnet lherzolite. Re contents do not correlate well with fertility and a $187 \mathrm{Re} / 188 \mathrm{Os}$ vs. ${ }^{8} \mathrm{O} \mathrm{Os} / 188 \mathrm{Os}$ isochron plot shows only a very poor correlation (Fig. 1). Moreover, $\mathrm{T}_{\mathrm{MA}}$ model ages range from $16.7 \mathrm{Ga}$ to future ages. Collectively, these observations point to recent $\mathrm{Re}$ mobility. It is noteworthy that the garnet lherzolite for which we have petrographic and chemical evidence of overprinting (LB-34, as described in Lee and Rudnick (1998)) has the highest $\operatorname{Re}$ concentration and the highest $\mathrm{Re} / \mathrm{Os}$ ratio. This suggests that $\mathrm{Re}$ addition occurred in some samples immediately before their entrainment in the host melilitite and was associated with Fe-enrichment, but not refertilization (i.e., $\mathrm{Ca}$ and $\mathrm{Al}$ are not enriched in these samples).

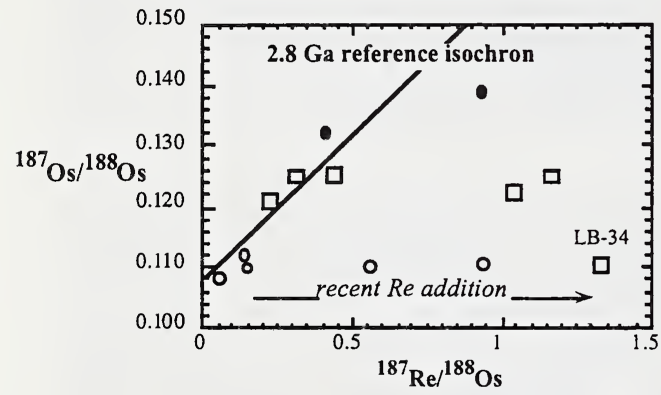

Figure 1: Re-Os isochron diagram showing effects of Re addition. Sample LB-34 shows two generations of olivine indicative of recent Fe-enrichment (Lee and Rudnick, 1998). Symbols: squares = gt bearing peridotites, open circles $=$ gt-free peridotites, closed circles $=$ glimmerite and pyrozenite.

$\mathrm{T}_{\mathrm{RD}}$ model ages range from $0.33 \mathrm{Ga}$ in a garnet lherzolite to $2.80 \mathrm{Ga}$ in a harzburgite, demonstrating that Archean-aged lithosphere is preserved beneath Labait. The two cumulate xenoliths have radiogenic ${ }^{187} \mathrm{Os} /{ }^{188} \mathrm{Os}$ and give future $\mathrm{T}_{\mathrm{RD}}$ ages. ${ }^{187} \mathrm{Os} /{ }^{188} \mathrm{Os}$ increases with depth (using $\mathrm{T}$ as a proxy for depth) and correlates well with fertility (Fig. 2). Trends similar to these are often interpreted as melt depletion trends (Reisberg and Lorand, 1995), which can be used to infer the age of melting from the initial ratios. The intercepts of the $\mathrm{Al}_{2} \mathrm{O}_{3}$ and $\mathrm{CaO}$ vs. ${ }^{187} \mathrm{Os} / 188 \mathrm{Os}$ plots give ${ }^{187} \mathrm{Os} / 188 \mathrm{Os}=0.105$ (or $3.4 \mathrm{Ga}$ ) and 0.1079 (or $2.8 \mathrm{Ga}$ ), respectively. However, neither of these trends pass through the primitive upper mantle composition (PUM), a condition that must be met if they truly reflect melt depletion. Thus these ages cannot be used as reliable indicators of the timing of lithosphere formation.

The best estimate for the age of the Tanzanian lithosphere is obtained from the ${ }^{187} \mathrm{Os} /{ }^{188} \mathrm{Os}$ of the abraded chromite separates. These range from 0.1076 to 0.1183 , corresponding to $\mathrm{T}_{\mathrm{RD}}$ ages of 2.9 to $1.3 \mathrm{Ga}$. Petrographic evidence of overgrowths on the chromites indicates that these should be considered minimum ages, since it is not certain whether all of the overgrowths were abraded away. We adopt a combination of the oldest chromite and whole rock $\mathrm{T}_{\mathrm{RD}}$ ages to reflect formation of the Tanzanian lithosphere between 2.9 and $2.5 \mathrm{Ga}$. A regressed line between the garnet-free peridotites and PUM on Fig. 2 yields an intercept compatible with these age estimates. However, the gtbearing peridotites plot well above these lines. There are three possible interpretations of this: 1) The garnet peridotites are distinctly younger than the gt-free peridotites (a line drawn between PUM and these scattered points yields an age of $\sim 1 \mathrm{Ga}$ ), suggesting a secular increase in depth of the lithosphere through time, 2) all the peridotites formed at approximately the same time but the 
deeper, gt-bearing samples experienced Re enrichment sometime after their formation, but well before their entrainment in the host basalt, and/or 3) the deep-seated peridotites experienced recent addition of radiogenic Os. We favor the latter two interpretations since 1) $\mathrm{T}_{\mathrm{RD}}$ ages of the gtperidotites are scattered, and are not indicative of a single younger melting event, $b) \operatorname{Re}$ is compatible in garnet (Righter and Hauri, 1997), which might make them more susceptible to $R e$ enrichment from passing melts compared to the gt-free samples, c) abundant sulfides in some garnet peridotites, coupled with deformed textures, suggests recent metasomatic enrichment of these samples (including sulfide addition), and d) the abraded rims of chromites in a recently metasomatized peridotite that has 400 ky zircons (Rudnick et al., 1998) are more radiogenic than the cores, suggesting incorporation of radiogenic Os during the metasomatism. The Re-Os results presented here demonstrate that Archean lithosphere persists to depths of $160 \mathrm{~km}$ beneath the edge of the Tanzanian craton.

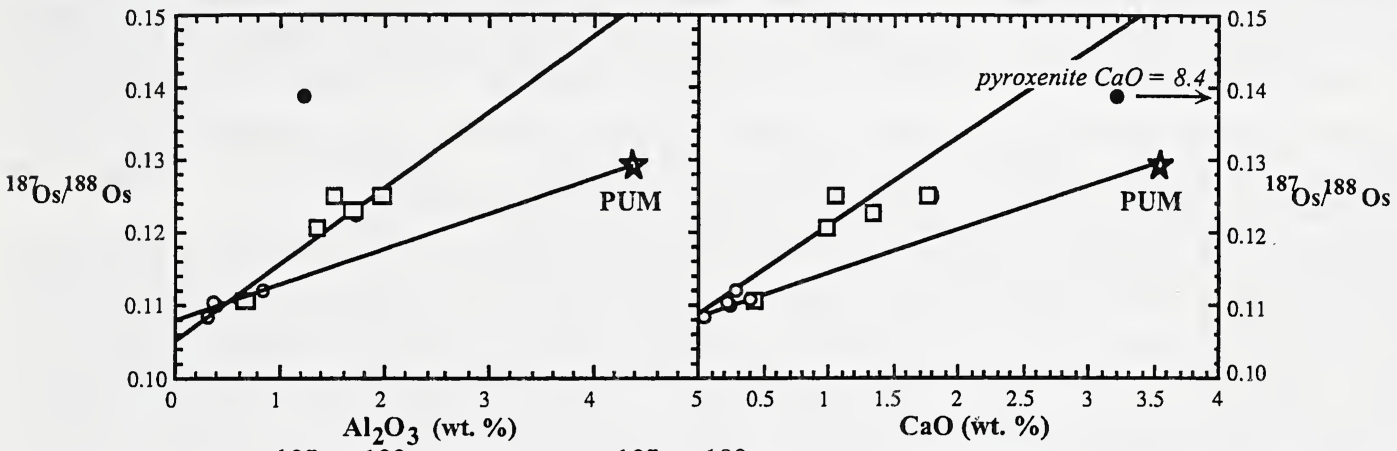

Figure 2: $\mathrm{Al}_{2} \mathrm{O}_{3}$ vs. ${ }^{187} \mathrm{Os} /{ }^{188} \mathrm{Os}$ and $\mathrm{CaO}$ vs. ${ }^{187} \mathrm{Os} /{ }^{188} \mathrm{Os}$. Symbols as in Fig. 1. PUM is primitive upper mantle composition from Meisel et al. (1996) and McDonough and Sun (1995).

\section{References}

Bell, K., and Dodson, M. H., 1980, The geochronology of the Tanzanian shield: J. Geol., v. 89, p. 109-128.

Dawson, J. B., 1992, Neogene tectonics and volcanicity in the North Tanzania sector of the Gregory Rift Valley: contrasts with the Kenya sector: Tectonophys., v. 204, p. 81-92.

Dawson, J. B., James, D., Paslick, C., and Halliday, A. M., 1997, Ultrabasic potassic low-volume magmatism and continental rifting in north-central Tanzania: association with enhanced heat flow: Russian Geol. Geophys., v. 38, p. 69-81.

Ebinger, C., Poudjom Djomani, Y., Mbede, E., Foster, A., and Dawson, J. B., 1997, Rifitng Archaean lithosphere: the Eyasi-Manyara-Natron rifts, East Africa: J. Geol. Soc., v. 154, p. 947-960.

Hart, S. R., and Ravizza, G. E., 1996, Os paritioning between phases in lherozlite and basalt, in Basu, A. a. H., S.R., ed., Earth Processes. Reading the Isotopic Code, Geophys. Monograph 95: Washington, D.C., American Geophysical Union, p. 123-134.

Lee, C.-T., and Rudnick, R. L., 1998, The origin and demise of cratonic lithosphere: a geochemical perspective from the Tanzanian craton: (this volume).

McDonough, W. F., 1994, Chemical and isotopic systematics of continental lithosheric mantle, in Meyer, H. O. A., and Leonardos, O., eds., Proceedings 5th Int. Kimberlite Conf., Spec. Publ.: Brasilia, CPRM, p. (in press).

McDonough, W. F., and Sun, S.-s., 1995, Composition of the earth: Chem. Geol., v. 120, p. 223-253.

Meisel, T., Walker, R. J., and Morgan, J. W., 1996, The osmium isotopic copmosition of the primitive upper mantle: Nature.

Nyblade, A. A., Pollack, H. N., Jones, D. L., Podmore, F., and Mushayandebvu, M., 1990, Terrestrial heat flow in East and Southern Africa: Journal of Geophysical Research, v. 95, p. 17,371-17,384.

Pearson, D. G., Carlson, R. W., Shirey, S. B., Boyd, F. R., and Nixon, P. H., 1995, The stabilisation of Archaean lithospheric mantle: A Re-Os isotope study of peridotite xenoliths from the Kaapvaal craton: Earth Planet. Sci. Lett., v. 134, p. 341-357.

Reisberg, L., and Lorand, J.-P., 1995, Longevity of sub-continental mantle lithosphere form osmium isotope systematics in orogenic peridotite massifs: Nature, v. 376, p. 159-162.

Righter, K., and Hauri, E. H., 1997, Re is compatible in garnet during matnle melting and magma genesis: 7th Annual Goldschmidt Conf., Lunar \& Planet. Inst., v. 921, p. 175.

Ritsema, J., Nyblade, A. A., Owens, T. J., Langston, C. A., and VanDecar, J. C., 1998, Upper mantle seismic velocity structure beneath Tanzania, East Africa: implications for th estability of cratonic lithosphere: J. Geophys. Res., v. (submitted).

Rudnick, R. L., Ireland, T. R., Gehrels, G., Irving, A. J., Chesley, J. T., and Hanchar, J. M., 1998, Dating mantle metasomatism: U-Pb geochronology of zircons in mantle xenoliths from Montana and Tanzania: (this volume). 